\title{
Risk-Based Thinking as a Basis for Efficient Occupational Safety Management in the Mining Industry
}

\author{
Marat Rudakov ${ }^{1, *}$, Elena Gridina ${ }^{1}\left(\mathbb{D}\right.$ and Jürgen Kretschmann ${ }^{2}$ \\ 1 Department of Industrial Safety, Saint Petersburg Mining University, 199106 Saint Petersburg, Russia; \\ Gridina_EB@pers.spmi.ru \\ 2 Technische Hochschule Georg Agricola University, 44787 Bochum, Germany; juergen.kretschmann@thga.de \\ * Correspondence: Rudakov_ML@pers.spmi.ru
}

check for updates

Citation: Rudakov, M.; Gridina, E.; Kretschmann, J. Risk-Based Thinking as a Basis for Efficient Occupational Safety Management in the Mining Industry. Sustainability 2021, 13, 470. https://doi.org/10.3390/su13020470

Received: 28 November 2020

Accepted: 1 January 2021

Published: 6 January 2021

Publisher's Note: MDPI stays neutral with regard to jurisdictional clai$\mathrm{ms}$ in published maps and institutional affiliations.

Copyright: (C) 2021 by the authors. Licensee MDPI, Basel, Switzerland. This article is an open access article distributed under the terms and conditions of the Creative Commons Attribution (CC BY) license (https:// creativecommons.org/licenses/by/ $4.0 /)$.
Abstract: This article deals with the role and the place of risk-based thinking in today's occupational safety and health (OSH) systems used by mining companies. A brief survey on modern challenges and pressures affecting companies, as well as on the structure of supply chains, is given. It is demonstrated that, despite all measures and actions that are being taken, occupational injuries in the mining sector: (a) remain a matter of serious concern and (b) should be examined and investigated through the lens of the company's complexity. The objective of the article is two-fold: to trace the evolution of risk-based thinking from quality management systems towards OSH management systems and to demonstrate how this approach can be implemented by a company performing open-pit mining operations. The matrix method along with the Fine and Kinney's method was used in assessing OSH risks, and the checklist method along with a Strengths-Weaknesses-OpportunitiesThreats (SWOT)analysis was used while assessing OSH opportunities. The results of the study make it possible to conclude that risk-based thinking incorporated into an OSH management system can be a robust and efficient instrument for OSH planning and implementation. This article contains an example of assessing OSH risks and opportunities for a dragline operator and also discusses the possible ways of using the data on the OSH risks and opportunities that were identified in OSH activities. The final part also contains comments and reflections on various risks mining companies are facing nowadays.

Keywords: mining; supply chains; complexity; pressures; risk-based thinking; occupational safety and health $(\mathrm{OSH})$; OSH management system; occupational fatalities; OSH risks and opportunities; open-pit

\section{Introduction: Increasing Complexity of Companies and Occupational Safety and Health Issues}

Nowadays, we can observe the processes of globalization and digitalization of economics. These processes, which are developing in line with "green economy" trends, make the contemporary company a very complex organism. The business and operational environment has changed considerably for the majority of organizations. One of the peculiarities of this change comes from the integration of various industrial, technical, political, economic, environmental and financial pressures, along with regulatory adjustments which ensue from these [1-3]. As has been underlined in many studies [4-6], the sustainable development of a company demands a continuous search for the right balance between social, environmental and economic performances, thus forming the complexity of the company's structure. For example, in paper [6], several measures of social sustainability were proposed to be incorporated in decision-making (labor equity, healthcare, safety and philanthropy).

As was underlined in [1], the operation of sectors, which were previously relatively autonomous and independent, became more complex as the number of stakeholders 
increased, including the advent of new technologies and interrelations between entities that are no longer isolated and independent.

Certainly, the companies of the mining sector do not work separately from other sectors. The term "supply chain" has become usual for both entrepreneurs and occupational safety and health $(\mathrm{OSH})$ practitioners. In general, a supply chain is governed by one company ("focal" company). Two main types of supply chain networks are considered in terms of OSH (Figure 1) [4,7]:

- Companies and their suppliers (supply chain)—the primary network;

- Companies linked together by contracting bonds (contracting chain)—the secondary or supporting network.

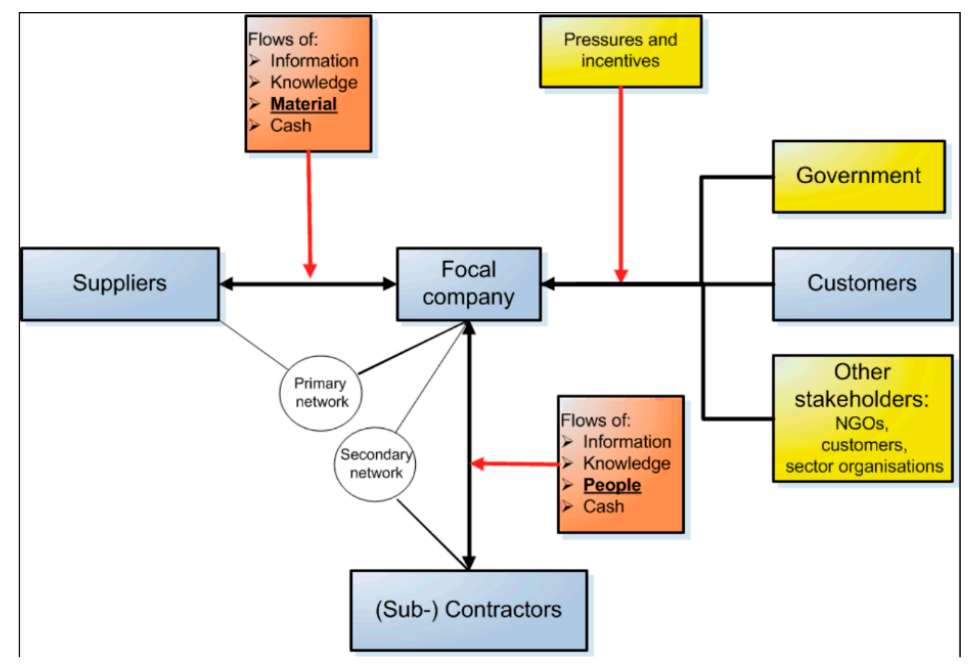

Figure 1. Two main types of supply chain networks, which are considered in terms of occupational safety and health $(\mathrm{OSH})[4,7]$.

Both networks (see Figure 1) are affected by stakeholders (the government, nongovernmental organizations and customers), as well as with various pressures and incentives. In many studies, the increasing complexity of supply chains has been marked (for example, [8]).

Moreover, the ongoing implementation of automation, information technology (IT) and artificial intelligence (AI) in the mining sector (centralized control of operators' activities and road quality monitoring, autonomous mining equipment, high-precision positioning, drilling control, etc.) also contributes to the increasing complexity of companies. Some authors speak of the "structural complexity" introduced through the heterogeneity of system components across different technological domains due to the increased integration among various systems, and the "dynamic complexity" which is manifested through the emergence of (even unexpected) system behavior in response to local changes in environmental and operational conditions $[1,3]$.

For example, in the study [1], we can see an example-the automation of several processes conveys more opacity in the system, with numerous control rules and new information technologies involved. In the study [9], we can see the discussion on the real qualitative effects of automation-it transforms human practice and forces people to adapt their skills and routines. Rather than reinventing or refining substitution-based methods, the authors of [9] propose that the more pressing question on human-automation coordination is "how do we make them get along together".

The complexity of the focal company's structure (internal challenge) along with various pressures (external challenge) also transforms the style of management. In today's practice, a top-level manager has to address various challenges almost every working day. This "labyrinth of challenges" gives rise to the strong desire to fix the problem at all costs and in the shortest time. Finding the fastest solution to the "labyrinth of challenges" often 
leads to a directive style of management, which does not accept either workers' opinions nor any corrective action.

Functioning under various pressures (industrial, technical, political, economic, environmental and financial), the contemporary company has to mobilize its internal capacities in order to address the occurring challenges. In several studies, the term "functional stupidity" is used, which may be characterized by an unwillingness or inability to mobilize three aspects of cognitive capacity: reflexivity, justification and substantive reasoning [10]. "Functional stupidity" refers to an absence of reflexivity, a planned state of ignorance resulting from tolerating unanswered questions and avoiding challenges to the status quo. In terms of $\mathrm{OSH}$, this may lead to workers' not participating in activities aimed at OSH improvements, taking OSH action that is not justified and occupational accident investigation, which is a more formal action than focusing on detecting the root causes of accidents.

It should be noted that even though state-of-the-art technologies and equipment are being introduced [11], digital technologies and intelligent systems are becoming widespread [12], and OSH training programs along with behaviour-based safety programs (safe behaviour audits) [13] and other measures [14] aimed at accident prevention are implemented accidents that still happen in mining companies, with some of them being fatal. Tables 1 and 2 show the official data on accidents in mining companies operating in the European Union and Russia, respectively.

Table 1. Occupational fatalities in the mining sectors of the European Union (28 countries $)^{1}$.

\begin{tabular}{ccc}
\hline Year & $\begin{array}{c}\text { The Number of Occupational } \\
\text { Fatalities (Coal and Lignite Mining) }\end{array}$ & $\begin{array}{c}\text { The Number of Occupational } \\
\text { Fatalities (Other Mining Sectors) }{ }^{2}\end{array}$ \\
\hline 2014 & 33 & 39 \\
2015 & 18 & 55 \\
2016 & 15 & 52 \\
2017 & 14 & 34 \\
2018 & not available & not available \\
\hline
\end{tabular}

${ }^{1}$ Source: Statistical Office of the European Union (Eurostat): https:/ / ec.europa.eu/eurostat/web/health/data/ database. ${ }^{2}$ Including mining support service activities.

Table 2. Occupational accidents and fatalities in the mining sectors of Russia ${ }^{1}$.

\begin{tabular}{ccc}
\hline Year & $\begin{array}{c}\text { The Number of Occupational } \\
\text { Accidents/Fatalities (Coal and Lignite Mining) }\end{array}$ & $\begin{array}{c}\text { The Number of Occupational } \\
\text { Accidents/Fatalities (Other Mining Sectors) }\end{array}$ \\
\hline 2014 & $8 / 26$ & $2 / 58$ \\
2015 & $8 / 20$ & $1 / 46$ \\
2016 & $8 / 56$ & $4 / 39$ \\
2017 & $3 / 16$ & $4 / 56$ \\
2018 & $5 / 17$ & $4 / 35$ \\
\hline
\end{tabular}

${ }^{1}$ Source: Federal Environmental, Industrial and Nuclear Supervision Service of the Russian Federation: http: //en.gosnadzor.gov.ru/.

The in-depth analysis of occupational accidents in the mining sector of the Russian Federation has shown that cause and effect (hazard and occupational accident) are sometimes not directly related (severe accidents and even occupational fatalities often resulted from minor hazards- the phenomenon of so-called "accident by chance"). In the study [1], a continuous drift to danger or failure is underlined which is almost impossible to capture in traditional of chain-of event analyses.

In several studies, it is noted that modern events may find their origin in unforeseen interactions between elements without visible links [1]. Additionally, in the paper [15], it is noted that when accidents are seen as complex phenomena, there is no longer an obvious relationship between the behavior of parts in the system (or their malfunctioning, e.g., "human errors") and system-level outcomes.

These circumstances compel us to seek solutions to emerging problems in different ways, and a systematic approach and risk-based thinking may constitute effective solutions. 
In fact, the focal company of the supply chain can take OSH action, but would not be able to address the OSH problems alone and separately from other companies. As a response to pressures and incentives, the majority of focal companies in the mining sector are implementing strategic OSH policies, starting internally (company's OSH policy, safe operations, risk reduction, a preventative culture, etc.) and extending it to the whole chain.

The risk (effect of uncertainty on objectives) plays the core role in the systems of management at the company level. Well-known types of risks such as market risk, actual inflation risk, credit risk, persistency risk, process risk, catastrophe risk, reputation risk, environmental risk, production risk, OSH risk and others form a risk media for company's activities and, therefore, they should be assessed and managed on a permanent basis. Actually, these risk media are a portrait of many interacting and interdependent pressures and, in fact, the company's success in competitive racing strongly depends on how successfully the company addresses existing and emerging risks.

The objective of the paper is two-fold: first, to analyze the role of the risk-based thinking approach in today's OSH management systems, and second, to demonstrate how this approach can be implemented in risk and opportunity assessment in the context of OSH management at an open-pit mine. The authors do hope that the risk-based approach may be instrumental in addressing the OSH challenge as one of the main complexities that modern mining companies are facing nowadays.

\section{Materials and Methods: OSH Management Systems and Assessment of Risks and Opportunities}

In 2011, The Organisation for Economic Co-operation and Development (OECD) published updated Guidelines for Multinationals [16]. These recommendations provide principles and standards for responsible business conduct in line with applicable laws and internationally recognized standards. Changes to the guidelines include: (a) a new human rights chapter; (b) a new and comprehensive approach to due diligence and responsible supply chain management representing significant progress relative to earlier approaches and (c) a proactive implementation agenda to assist enterprises in meeting their responsibilities as new challenges arise.

In our view, OSH management systems may be considered as one of the valid instruments to address new challenges-i.e., new and emerging occupational risks. Occupational safety and health are some of the most important issues for the mining industry such as the high rates of accidents (see Tables 1 and 2 above) and occupational diseases remain serious challenges that affects productivity, competitiveness and the social protection system that includes treatment, rehabilitation and benefits provided to those who suffered from accidents.

In recent years, many publications have appeared that are devoted to applying the systems approach to OSH management in mining companies [17,18]. This approach is based on the requirements stated in the following documents.

The Guidelines on Occupational Safety and Health Management Systems (ILO-OSH2001), developed by the International Labour Organization (ILO), provide a framework for developing an OSH management system at both the national and organizational levels. The guidelines are based on OSH principles that are universally recognized and were approved by the ILO's tripartite partners: employee, employer and state authority representatives. This three-pronged approach aids in developing a reliable and flexible management system and for building the foundation for a sustainable safety culture in a company. According to the guidelines, involving employers, employees and authorities results in the continuous improvement of a company's OSH indicators. From a legal point of view, the guidelines are not mandatory but they are widely used as a foundation for OSH management systems based on the plan-do-check-act Plan-Do-Check-Act (PDCA) methodology. It is also advisable that there should be national laws and standards governing the implementation of OSH management systems. The methodology based on the PDCA cycle allows for continuous improvement of the company's OSH management system. The ILO-OSH-2001 guidelines give general recommendations for developing or improving an OSH manage- 
ment system whose performance largely depends on the motivation and competence of the company's management. Risk assessment and management at the workplace are, in fact, the pillars of the OSH management system as they help identify the main OSH risks for workers and planning OSH measures in a rational way. What makes the guidelines special is the emphasis on employee participation in OSH management as an essential element of $\mathrm{OSH}$ management. In our experience, employees who work for mining companies and are involved in OSH management (for example, in risk assessment procedures) become strongly motivated by this process and begin to consider OSH not as a set of various rules and instructions, but as a continuous process in the workplace that they are also responsible for and that their health and lives depend on.

The BS OHSAS 18001:2007 standard ("Occupational health and safety management systems-Requirements") is, in essence, similar to the ILO-OSH-2001 guidelines. Both documents were developed based on PDCA principles and regulate risk assessment and management procedures. A detailed comparative analysis of these two documents is beyond the scope of this article, we only want to note that the BS OHSAS 18001:2007 standard does not mention the implementation of the management system being discussed at the national level as the standard developed for companies. In addition, the management model proposed in this standard was created for integration with other management systems that are regulated-for example, by such standards as ISO 9001:2015 [19] and ISO 14001:2015 ("Environmental management systems-Requirements with guidance for use").

In March 2018, the new ISO 45001 standard ("Occupational health and safety management systems-Requirements with guidance for use") was issued [20]. When developing this international standard, provisions were taken into account that are stated in such documents as the BS OHSAS 18001:2007 standard, the ILO-OSH-2001 guidelines, various national standards, international labor standards and ILO conventions. A three-year transition period was announced (until March 2021) to give companies the opportunity to have their OSH management systems recertified as compliant with the requirements of the ISO 45001 international standard.

It is in the ISO 45001 international standard, in contrast to the ILO-OSH-2001 guidelines and the BS OHSAS 18001:2007 standard, that an approach based on risk-based thinking manifests itself: the document regulates the definition and assessment of both risks and opportunities (the ILO-OSH-2001 guidelines and the BS OHSAS 18001:2007 standard deal exclusively with risks).

(Generally speaking, the approach based on the PDCA cycle and on taking preventive action is aimed at minimizing the occurrence of hazards and high levels of risks associated with them, thus helping overcome, to some extent, the "structural complexity" and "dynamic complexity" of the company.)

The ISO 45001 standard describes two groups of risks and opportunities:

1. OSH risks and opportunities, i.e., risks and opportunities associated with work activities that are performed by employees, and primarily those associated with hazards;

2. other risks and opportunities for the OSH management system as a whole, such as changes to national regulations, orders from and fines imposed by state regulatory bodies and inspections, senior management changes, etc.

Risks and opportunities themselves, as well as processes associated with them, should be thoroughly documented in, for example, the company's risk assessment standard, risk assessment registers, action plans for eliminating and minimizing risks, financing documents connected with action plans, etc.

The concept of risk-based thinking, which was introduced by the International Organization for Standardization (ISO) in one of its quality management standards [19], is a key factor when applying the process approach to management in a company, along with the plan-do-check-act (PDCA) cycle. Risk-based thinking allows a company to identify factors that can cause the results of the company's processes and quality management to be different from what was planned, and to use proactive problem management controls in order to minimize negative consequences and maximize opportunities [19]. In recent 
years, the use of the approach based on risk-based thinking has expanded significantly, extending to management areas that are not directly connected with product quality. What proves that this approach is successful is the fact that a special standard (ISO 9004:2009) was published [21] which regulates how this approach should be applied to management procedures (in a broad sense) in order to ensure the sustainable development of a company.

Recent scientific papers broadly discuss the issues of risk assessment and management and look at them from different angles. Along with previously marked studies, the papers $[22,23]$ cover risk issues in the context of corporate social responsibility and company sustainability in the mining sector. The papers [24,25] demonstrate how risks can be assessed using the checklist method applied to carbon capture and storage (CCS) projects. The paper [26] touches upon the issues of environmental risks in mining waste management and disposal, and the paper [27] discusses the issues of minimizing economic risks and optimizing costs connected with OSH in the mining sector. The latest publications by the European Agency for Safety and Health at Work (EU OSHA) give detailed descriptions of methods for assessing and minimizing risks associated with contracting COVID-19 at work, a virus that is described as an occupational health hazard of biological origin [28,29].

The variety of risk assessment methods being applied, which are described in detail in the ISO 31010 standard [30], enables a researcher as well as a professional working for a company to choose the method that is most applicable to a particular economic activity, taking into account how qualified the top management and the user of the method are. For example, bow-tie analysis (BTA) can be successfully used in both relatively simple models for accident risk assessment [31] and complex software systems. RISKGATE, a well-known Australian interactive online system, can serve as an example. It can be used to assess risks in the coal industry [32] by identifying the key events that initiate accidents (when control over the situation is lost) and creating the lists of causes and measures to control each initiating event. The RISKGATE system uses the BTA model, as it is the most illustrative and makes it possible to study the development of undesirable events (both accidents and incidents) in a system and thoroughly analyze how they are controlled in order to prevent or minimize their consequences. When selecting a method of risk assessment, OSH specialists have an opportunity to get acquainted with RISKGATE at the site of the very system (http:/ / www.riskgate.org/).

Of course, this brief literature review does not claim to be exhaustive and mainly shows how diverse the applications of risk assessment models can be. After all, it is the researcher or OSH manager working for a mining company who makes the final selection of an OSH risk assessment method and develops measures aimed at eliminating or minimizing the risks identified.

As part of preparing for certification to comply with the requirements of the ISO 45001 standard, an assessment of OSH risks and opportunities was carried out at an open-pit mine (the first group of risks and opportunities).

\subsection{OSH Risk Assessment}

The introduction of new technologies has led to a significant increase in productivity in open-pit mining. An example of this is the leading Russian coal mining company LLC "SUEK"- over the past ten years, the average excavator bucket capacity grew by a factor of 1.1-3, and the average dump truck capacity grew by a factor of 1.5-2.4. Consequently, excavation productivity grew by a factor of $1.2-2.9$, and transportation productivity grew by a factor of 1.3-3.4. (One of the subsidiaries of LLC "SUEK", that performs open-pit coal mining, displayed the following data: the average bucket capacity of excavators increased from 11.9 to $21 \mathrm{~m}^{3}$, their productivity from 2267 to 7948 thousand $\mathrm{m}^{3}$ /year and the average carrying capacity of dump trucks from 89.4 to 167.5 tons. The average power of drilling equipment during this period increased from 144 to $252 \mathrm{~kW}$ and the average speed of advancement of the mining front has risen from 75 to $230 \mathrm{~m} /$ year [33].) 
In addition to the aforesaid analysis, it should be noted that an increase in productivity without streamlining the production processes increases the likelihood of occupational injuries, and the use of powerful and heavy equipment increases their possible severity.

At the preliminary stage of risk assessment, a register of accidents covering the past ten years of the mine's operation was analyzed and the checklist method was used to interview the employees in order to identify the frequency of hazard occurrence when performing production operations. In total, 72 employees representing key workers' professions were interviewed (bus driver, dump truck drivers, excavator operator, operator of drilling installation, specialist in blasting operations, electrician). Hazard identification was carried out for three possible situations:

- normal operating conditions;

- abnormal operating conditions characterized by the emergence of new hazards that are not encountered in normal operating conditions;

- $\quad$ emergency operating conditions (taking into account how abnormal operation evolves into an emergency at all stages of emergency containment and management).

Risk assessment was carried out using a combination of methods that included the Fine and Kinney method, which grades risks by their probability of occurrence and severity in quite simple forms understandable for all workers (Tables 3 and 4, respectively), along with matrix method.

Table 3. Probability rating.

\begin{tabular}{cc}
\hline Hazard Occurrence Frequency/Likelihood & Probability Rating, P \\
\hline Less than once every 10 years/very unlikely & 1 \\
From 1 time in 10 years to 1 time a year/unlikely & 2 \\
From 1 time per year to 1 time per month/possible & 3 \\
From 1 time per month to 1 time per shift/likely & 4 \\
1 time or more per shift/almost certain & 5 \\
\hline
\end{tabular}

Table 4. Severity rating.

\begin{tabular}{cc}
\hline Consequence & Severity Rating, $\mathbf{Q}$ \\
\hline Slight injury & 1 \\
Minor injury & 2 \\
Severe injury & 3 \\
Single fatality & 4 \\
Multiple fatalities & 5 \\
\hline
\end{tabular}

Risk itself (R) was assessed using Formula (1):

$$
\mathrm{R}=\mathrm{P} \cdot \mathrm{Q}
$$

A matrix representation of the assessment results using cell shading for better visualization can be seen in Table 5. When assessing the level (degree) of risk for each of the hazards being analyzed, a risk matrix was used, in which the levels of probability and severity are combined. A risk was assigned to a particular company by comparing its value with the risk tolerance grades presented in Table 5.

Table 5. Grades of the risks assessed.

\begin{tabular}{ccc}
\hline & Risk Grades \\
\hline $1-2$ & $3-9$ & $10-25$ \\
Low risks ${ }^{1}$ & Tolerable risks ${ }^{2}$ & High risks ${ }^{3}$ \\
\hline $\begin{array}{l}{ }^{1} \text { No special safety measures are required; }{ }^{2} \text { employees are given clearance if special safety measures are taken; }{ }^{3} \\
\text { employees are not given clearance until protective measures are taken and the level of risk decreases and becomes } \\
\text { tolerable (yellow zone) or low (green zone). }\end{array}$
\end{tabular}




\subsection{OSH Opportunity Assessment}

Methods for assessing OSH opportunities are currently not regulated by any documents. This is why we chose a combination of methods that includes: (a) analysis of risk assessment results, (b) interviewing the employees (workers, line managers, and top management) and (c) SWOT analysis.

\section{Results}

\subsection{OSH Risk Assessment Results}

Based on the risk assessment results obtained in this study, risk charts were created for a number of professions in open-pit mining (Table 6). A fragment of the risk chart for the dragline operator, which represents the category of workers, is given as an example in Appendix A. Table 7 displays the distribution of risk grades for categories of professions.

Table 6. Categorization of professions covered with risk charts.

\begin{tabular}{ccc}
\hline Category of Professions & The Number of Employees & $\%$ \\
\hline Workers & 248 & 91.2 \\
Line managers, mining support & 21 & 7.7 \\
service managers, OSH specialists & 3 & 1.1 \\
Top management of the open pit & 272 & 100 \\
Total & & \\
\hline
\end{tabular}

Table 7. Distribution of risk grades.

\begin{tabular}{cccc}
\hline Category of Professions & Low Risks & Tolerable Risks & High Risks \\
\hline $\begin{array}{c}\text { Workers } \\
\text { Line managers, mining support }\end{array}$ & $8(3 \%)$ & $54(22 \%)$ & $186(75 \%)$ \\
$\begin{array}{c}\text { service managers, } \\
\text { OSH specialists }\end{array}$ & $4(19 \%)$ & $16(76 \%)$ & $1(5 \%)$ \\
Top management of the open pit & $3(100 \%)$ & nil & nil \\
\hline
\end{tabular}

Analysis of the risk charts made it possible, firstly, to detect key reasons for occupational accidents, secondly, to discover "bottlenecks" in OSH management and, thirdly, to set up priorities in OSH action focused on the improvement of OSH conditions of workers of the open pit. For example, by analyzing the risk assessment results and the data from the register of accidents, the following reasons were identified for occupational injuries sustained while operating a dragline excavator:

- $\quad$ personal negligence-i.e., the fact that the employee who sustained an injury did not check the workplace for hazards before starting;

- organizational reasons (insufficient control on the part of officials over whether or not production operations are carried out in compliance with safety instructions);

- impact from equipment (for example, situations in which a worker stands right under an excavator bucket, or the excavator operator starts turning the machine without giving a signal and checking first if anyone is standing near, or the excavator operator decides to move the machine to a new location of their own will);

- reasons associated with rockfalls (discrepancy between the documents regulating mining operations and the real working conditions in the open-pit mine; failure to comply with the requirements stated in the documents regulating mining operations);

- reasons associated with electric shock (violations of electrical safety regulations; lack of control over operations using high-voltage equipment; using faulty electrical equipment).

\subsection{OSH Opportunity Assessment Results}

When assessing OSH opportunities, it was noted that this stage is, in fact, is an integral part of risk management which consists of: 
- hazard identification;

- risk assessment;

- planning risk management measures;

- assessing whether it is possible to eliminate risks;

- implementing measures aimed at eliminating or minimizing risks;

- residual risk assessment.

When assessing OSH opportunities in the context of risk management, a SWOT analysis was carried out, with the root causes of occupational injuries noted above identified as weaknesses. An example of assessing opportunities for a dragline operator is given in Table 8.

Table 8. Weaknesses and OSH opportunities for a dragline operator.

\begin{tabular}{lll}
\multicolumn{1}{c}{$\begin{array}{c}\text { S } \\
\text { Strengths }\end{array}$} & \multicolumn{1}{c}{$\begin{array}{c}\text { W } \\
\text { Weaknesses }\end{array}$} & \multicolumn{1}{c}{$\begin{array}{c}\text { O } \\
\text { Opportunities }\end{array}$} \\
\hline 1. Personal negligence & $\begin{array}{l}\text { 1. An existing methodology for } \\
\text { conducting behavior-based } \\
\text { safety audits }\end{array}$ \\
\hline 2. Using faulty electrical equipment & $\begin{array}{l}\text { 2. The opportunity to quickly replace } \\
\text { faulty equipment }\end{array}$ \\
\hline $\begin{array}{l}\text { 3. Lack of control over operations } \\
\text { using high-voltage equipment }\end{array}$ & $\begin{array}{l}\text { 3. Employing a worker who will be } \\
\text { responsible for safety monitoring }\end{array}$ \\
\hline $\begin{array}{l}\text { 4. Discrepancy between the } \\
\text { documents regulating mining } \\
\text { operations and the real } \\
\text { working conditions }\end{array}$ & $\begin{array}{l}\text { 4. Having the documents reviewed } \\
\text { by an expert organization }\end{array}$ \\
\hline $\begin{array}{l}\text { 5. Negligence on the part of the } \\
\text { excavator operator }\end{array}$ & $\begin{array}{l}\text { 5. The opportunity to take } \\
\text { disciplinary action and conduct } \\
\text { behavior-based safety audits; the } \\
\text { opportunity to replace the operator } \\
\text { with another employee }\end{array}$ \\
\hline
\end{tabular}

It should be noted that assessment of opportunities is not an end in itself for the company; it is inextricably linked with risk management planning and implementation. Table 5, presented above (which in its full form covers all the jobs at the open-pit mine), served as the foundation for the annual OSH improvement plan.

Thus, we believe that this stage is one of the most important in drawing up plans describing measures that will prove successful in eliminating or minimizing risks.

\section{Discussion}

As it may be seen, the root causes of occupational injuries listed above in many cases have an organizational origin, resulting from complexity, which is a matter of interactions between simple interdependent components/systems, humans, IT, etc. These interactions create both significant uncertainties and overall opaqueness in the system, which consequently makes the operator dependent on indirect information reducing his capacity of immediate analysis and ulterior action. Consequently, the safety margin is reduced, and the system becomes more vulnerable to accidents [1,15,34,35]. In particular, in the study [1], it was underlined that in the context of the complexity and the functional opaqueness of the system, it is difficult for the workers to anticipate its global behavior based on the behavior of its components in interactions.

OSH risks and opportunities are usually assessed, as the example given above shows, at the level of departments in a company with the participation of the OSH department. However, risks and opportunities for the OSH management system as a whole should be assessed at the top management level. This assessment is in progress and is being discussed at the open-pit mine but some examples of risks can already be given: 
- changes in the price of the mineral being mined by the company, which may lead to a decrease in spending on $\mathrm{OSH}$ issues;

- a shortage of qualified personnel, including experienced blue-collar workers, which indirectly contributes to growth in the number of occupational injuries;

- legal action that is taken against the company based on the results of state inspections;

- changes to OSH regulations causing the need to make significant adjustments to the company's OSH management system;

- economic sanctions.

In our opinion, the risk-based thinking approach can be implemented at the level of departments as follows: risk assessment, identifying the root causes of injuries, identifying weaknesses, assessing opportunities to eliminate risks and planning and implementing $\mathrm{OSH}$ measures.

It should also be noted that the preliminary stage of risk and opportunity assessment did not require spending a long time training the company's OSH professionals and senior management, and the risks and opportunities that were revealed are currently being used for the following purposes:

- planning measures aimed at eliminating, minimizing and managing risks;

- conducting safety training for the company's employees;

- informing employees about hazards in the workplace;

- providing employees with personal protective equipment;

- selecting candidates for performing particularly difficult and hazardous tasks.

\section{Conclusions and Final Comments}

As highlighted in this article, the use of a risk and opportunity assessment allows the researcher or OSH specialist to effectively identify "bottlenecks" in ensuring the safety of workers, as well as to plan and implement OSH measures mainly focused on the professional group of "workers", which is the category of the most vulnerable employees. The SWOT analysis method may be used as a "link" between the root causes of occupational injuries (weaknesses) and OSH action to take (opportunities) in order to eliminate those causes in the future. Strictly speaking, assessment of risks and opportunities should be considered as two components of the same process within the OSH management system.

The study that was performed at the open-pit mine has demonstrated that the implementation of the ISO 45001 standard at mining companies allows a more detailed identification to be put in place and the elimination of the root causes of hazards, which will ultimately reduce occupational traumatism.

In general, the various risks that the company is facing are affecting economic development and productivity. In particular, OSH risks resulting in accidents and ill health are the causes of so-called "direct" and "indirect" costs of poor working conditions. Examples of "direct" costs are disruption to business and ongoing lost production from worker absence, workers' lost wages and possible costs of retraining for a different job, first aid, medical and rehabilitation costs, insurance costs and possibly higher future premiums and costs of compensation. Examples of "indirect" costs are costs of recruitment of replacement worker, poorer long-term worker employability because of injury, loss of quality of life and general welfare, lower motivation to work and workforce morale, increased absenteeism, poorer company reputation and client and public relations and damage to the environment (e.g., from chemical incidents) [36].

Vice versa, similar productivity benefits from good OSH conditions accrue at the company and national levels. Moreover, several studies [36,37] show a strong correlation between national competitiveness and the nation's incidence rates of occupational accidents, and the international standard on social responsibility (ISO 26000:2010) defines labor practices as being among the seven core subjects of social responsibility. Meanwhile, the endless competitiveness race ("do-more-and-better-with-less" paradigm [1]) especially in the mining sector, along with impacting internal and external challenges and pressures often results in work-related stress for both managers and workers. As was underlined in 
the published ILO manual [38], stress has many negative impacts, including circulatory and gastrointestinal diseases, other physical problems, psychosomatic and psychosocial problems, and low productivity. In fact, a workplace stress prevention policy should be integrated into the overall OSH policy of the company. Solving stress problems at work is one of the challenges to ensuring a productive and healthy working life.

These days, the mining industry has become a very complex system. This circumstance, of course, has very profound consequences. Accidents are becoming more global amid the emergence of new technologies and complex relationships within and amongst organizations. Nevertheless, most of the Russian and EU mining companies are currently faced with the problem that the so-called "easy to tackle" causes of incidents and accidents have already been eliminated (outdated equipment has been replaced with modern equipment, technologies meet world standards, etc.). That is why highly qualified erudite employees are required who are able to think creatively and perceive a situation in three dimensions. At the same time, certain schemes of the "cause-effect" type only help to deal with the situation, and do not simplify approaches. Of course, the mining industry is now subject to systemic complication. Operators need to process a large amount of information, which sometimes reduces their ability to make immediate conclusions and correct actions, thus reducing the safety level. However, the "risk assessment chart" (see Annex A with the example for the dragline excavator operator) has been designed to help "see the main thing behind the small and insignificant" and avoid dangerous situations by means of targeted measures.

The risk-based thinking approach to OSH management is an effective tool for planning activities within the PDCA cycle. The implementation of this approach does not require significant investments of money and time, and the results obtained from the assessment of risks and opportunities can be used for various purposes in OSH management.

Nowadays, big mining companies are actively preparing for certification to comply with the ISO 45001 requirements as they realize that the health and lives of workers are integral components of both economic development and the preservation of human capital [39].

The pace of scientific progress in the mining industry requires companies to constantly apply new technologies and approaches to management. Therefore, the management of these organizations also turns out to be more challenging due to significant uncertainties created through complexity. Contemporary mining companies also fall into this category $[1,40]$.

In this regard, it would be appropriate to quote from the famous novel Through the Looking-Glass, and What Alice Found There by Lewis Carroll: "You see, it takes all the running you can do, to keep in the same place. If you want to get somewhere else, you must run at least twice as fast as that!".

Mining companies realize how true these words are almost every single day.

Author Contributions: Conceptualization, M.R. and J.K.; methodology, M.R. and E.G.; validation, E.G.; investigation, E.G.; writing—original draft preparation, M.R.; writing-review and editing, J.K. All authors have read and agreed to the published version of the manuscript.

Funding: This research received no external funding.

Institutional Review Board Statement: Not applicable.

Informed Consent Statement: Not applicable.

Data Availability Statement: The data presented in this study are available on request from the corresponding author. The data are not publicly available due to obligations of Saint Petersburg Mining University not to disclose the results of joint research with companies.

Acknowledgments: Authors acknowledge LLC "Siberian Coal Energetic Company (SUEK)" for material provided.

Conflicts of Interest: The authors declare no conflict of interest. 


\section{Appendix A}

Table A1. Example of the risk chart for the dragline excavator operator.

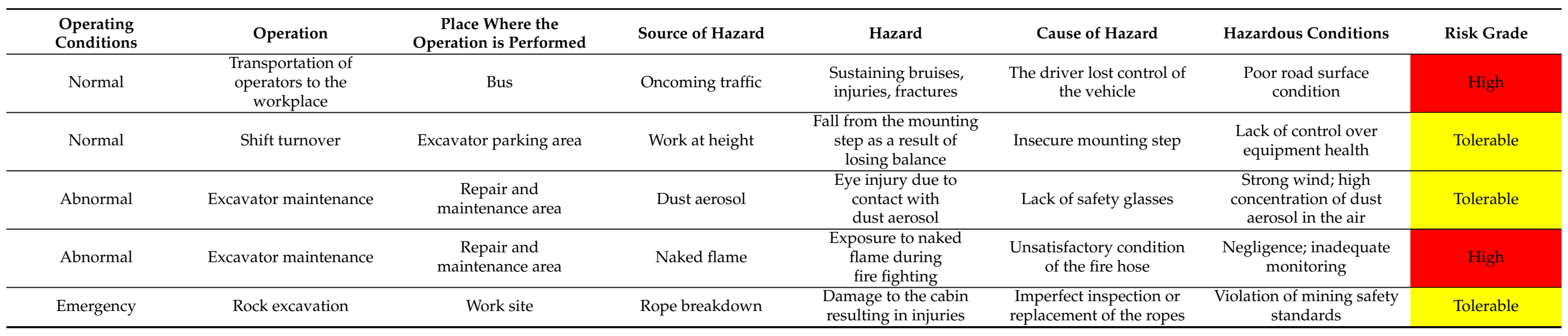




\section{References}

1. Komljenovic, D.; Loiselle, G.; Kumral, M. Organization: A new focus on mine safety improvement in a complex operational and business environment. Int. J. Min. Sci. Technol. 2017, 27, 617-625. [CrossRef]

2. Arstad, I.; Aven, T. Managing major accident risk: Concerns about complacency and complexity in practice. Saf. Sci. 2017, 91, 114-121. [CrossRef]

3. Zio, E. Challenges in the vulnerability and risk analysis of critical infrastructures. Reliab. Eng. Syst. Saf. 2016, 152, 137-150. [CrossRef]

4. Seuring, S.; Müller, M. From a literature review to a conceptual framework for sustainable supply chain management. J. Clean. Prod. 2008, 16, 1699-1710. [CrossRef]

5. Carter, C.R.; Easton, P.L. Sustainable supply chain management: Evolution and future directions. Int. J. Phys. Distrib. Logist. Manag. 2011, 1, 46-62. [CrossRef]

6. Hutchins, M.; Sutherland, J.W. An exploration of measures of social sustainability and their application to supply chain deci-sions J. Clean. Prod. 2008, 16, 1688-1698. [CrossRef]

7. European Agency for Safety and Health at Work (EU-OSHA). Promoting Occupational Safety and Health Through the Supply Chain. Available online: https://osha.europa.eu/en/publications/literature_reviews/promoting-occupational-safety-andhealth-through-the-supply-chain (accessed on 21 December 2020).

8. Walters, D.; James, P. What motivates employers to establish preventive management arrangements within supply chains? Saf. Sci. 2011, 49, 974-987. [CrossRef]

9. Dekker, S.W.A.; Woods, D.D. MABA-MABA or Abracadabra? Progress on Human-Automation Co-ordination. Cogn. Technol. Work 2002, 4, 240-244. [CrossRef]

10. Alvesson, M.; Spicer, A. A Stupidity-Based Theory of Organizations. J. Manag. Stud. 2012, 49, 1194-1220. [CrossRef]

11. Kazanin, O.I.; Sidorenko, A.A.; Meshkov, A.A. Organizational and technological principles of realization of the modern high productive longwall equipment capacity. Coal 2019, 12, 4-13.

12. Litvinenko, V.S. Digital Economy as a Factor in the Technological Development of the Mineral Sector. Nat. Resour. Res. 2019, 28, 1-21. [CrossRef]

13. Kretschmann, J.; Nguyen, T.H.N. Adaptation Saves Lives! Transferring Excellence. In Occupational Safety and Health Management from German to Southeast Asian Mining, 2nd ed.; Hong Duc Publishing House: Hanoi, Vietnam, 2014.

14. Kretschmann, J. Sustainable Change of Coal-Mining Regions. Min. Metall. Explor. 2020, 37, 167-178. [CrossRef]

15. Dekker, S.; Cilliers, P.; Hofmeyr, J.-H. The complexity of failure: Implications of complexity theory for safety investigations. Saf. Sci. 2011, 49, 939-945. [CrossRef]

16. Organisation for Economic Co-operation and Development, OECD Guidelines for Multinational Enterprises. 2011. Available online: http: / / www.oecd.org/ dataoecd / 43/29/48004323.pdf (accessed on 21 December 2020).

17. Chemezov, E.N. Industrial safety principles in coal mining. J. Min. Inst. 2019, 240, 649-653. [CrossRef]

18. Filimonov, V.A.; Gorina, L.N. Development of an occupational safety management system based on the process approach. J. Min. Inst. 2019, 235, 113-122. [CrossRef]

19. International Organization for Standardization (ISO). ISO 9001:2015. Quality Management Systems-Requirements. Available online: https:/ / www.iso.org/standard/62085.html (accessed on 10 August 2020).

20. International Organization for Standardization (ISO). ISO 45001:2018 Occupational Health and Safety Management SystemsRequirements with Guidance for Use. Available online: https:/ / www.iso.org/standard/63787.html (accessed on 10 August 2020).

21. International Organization for Standardization (ISO). ISO 9004:2018. Quality Management-Quality of an Organization-Guidance to Achieve Sustained Success. Available online: https:/ /www.iso.org/standard/70397.html (accessed on 10 August 2020).

22. Keenan, J.; Kemp, D.; Owen, J. Corporate responsibility and the social risk of new mining technologies. Corp. Soc. Responsib. Environ. Manag. 2019, 26, 752-760. [CrossRef]

23. Litvinenko, V.S.; Tsvetkov, P.S.; Molodtsov, K.V. The social and market mechanism of sustainable development of public companies in the mineral resource sector. Eurasian Min. 2020, 1, 36-41. [CrossRef]

24. Cherepovitsyn, A.E.; Ilyinova, A.A.; Evseeva, O.O. Stakeholders management of carbon sequestration project in the state -business-society system. J. Min. Inst. 2019, 240, 731-742. [CrossRef]

25. Ilyinova, A.A.; Cherepovitsyn, A.E.; Evseeva, O.O. Stakeholder Management: An Approach in CCS Projects. Resources 2018, 4, 83. [CrossRef]

26. Nevskaya, M.A.; Seleznev, S.G.; Masloboev, V.A.; Klyuchnikova, E.M.; Makarov, D.V. Environmental and business challenges presented by mining and mineral processing waste in the Russian Federation. Minerals 2019, 9, 445. [CrossRef]

27. Gendler, S.G.; Grishina, A.M.; Kochetkova, E.A. Optimization of expenditures for labor protection at deep mining. Eurasian Min. 2017, 2, 35-39. [CrossRef]

28. European Agency for Safety and Health at Work (EU-OSHA). COVID-19: Back to the Workplace. Adapting Workplaces and Protecting Workers. 2020. Available online: https://osha.europa.eu/en/publications/covid-19-back-workplace-adaptingworkplaces-and-protecting-workers/view (accessed on 7 August 2020). 
29. European Agency for Safety and Health at Work (EU-OSHA). Biological Agents and Work-Related Diseases: Results of a Literature Review, Expert Survey and Analysis of Monitoring Systems. 2019. Available online: https://osha.europa.eu/en/publications/ biological-agents-and-work-related-diseases-results-literature-review-expert-survey-and/view (accessed on 7 August 2020).

30. ISO/IEC 31010:2009 Risk Management—Risk Assessment Techniques. Available online: https://www.iso.org/standard/51073. html (accessed on 10 August 2020).

31. Kovshov, S.V.; Alimhanova, T.A.; Kitsis, V.M. Ranking of the section of East Siberia Pacific Ocean main pipeline by accident probability using Bow-tie method and CheckList support tool. J. Pipeline Syst. Eng. Pract. 2020, 11, 1-11. [CrossRef]

32. Kirsch, P.; Shi, M.; Sprott, D. Riskgate: Industry Sharing Risk Controls Across Australian Coal Operations. Aust. J. Multi-Discip. Eng. 2014, 11, 47-58. [CrossRef]

33. Kuletsky, V.N.; Zhunda, S.V.; Dovgenok, A.S. Organization of ensuring the safety of production processes in a coal mine in the face of an increase in the capacity of mining equipment. Ugol' 2020, 2, 35-40. [CrossRef]

34. Marais, K.; Saleh, J.H.; Leveson, N.G. Archetypes for organizational safety. Saf. Sci. 2006, 44, 565-582. [CrossRef]

35. Montibeller, G.; Winterfeldt, D. Cognitive and motivational biases in decision and risk analysis. Risk Anal. 2015, 35, 1230-1251. [CrossRef]

36. International Labour Organization (ILO). Occupational Safety and Health: Synergies between Security and Productivity. Geneva, March 2006. Available online: https:/ /www.ilo.org/global/topics/safety-and-health-at-work/events-training/eventsmeetings/WCMS_110380/lang--en/index.htm (accessed on 30 August 2020).

37. Malin Shooks, M.; Johansson, B.; Andersson, E.; Lööw, J. Safety and Health in European Mining. A Report on Safety and Health, Statistics, Tools and Laws, Produced for the $\mathrm{I}^{2}$ Mine (Innovative Technologies and Concepts for the Intelligent Deep Mine of the Future) project. Luleå Univ. Technol. 2014. Available online: https:/ / www.researchgate.net/publication/319530908 (accessed on 30 August 2020).

38. International Labour Organization (ILO). Stress prevention at work checkpoints. Geneva. 2012. Available online: https: / /www.ilo.org/wcmsp5/groups/public/---dgreports/---dcomm/---publ/documents/publication/wcms_168053.pdf (accessed on 22 December 2020).

39. Makhova, L.A.; Lapinskas, A.A.; Haykin, M.M. Economic challenges and problems related to natural resources management as a consequence of human capital accumulation. Utop. Y Prax. Latinoam. 2019, 5, 138-143.

40. Komljenovic, D.; Abdul-Nour, G.; Popovic, N. An approach for strategic planning and asset management in the mining industry in the context of business and operational complexity. Int. J. Min. Eng. 2015, 4, 338-360. [CrossRef] 